\title{
Severe rheumatoid arthritis hand deformity
}

\author{
Alain Harb, ${ }^{1}$ Khaled Shawwa, ${ }^{2}$ Abdul Hamid Alraiyes, ${ }^{3}$ M Chadi Alraies ${ }^{1}$
}

1 Department of Hospital Medicine, Cleveland Clinic, Cleveland, Ohio, USA

${ }^{2}$ American University of Beirut Medical Center, Beirut, Beirut, Lebanon

${ }^{3}$ Department of Pulmonary

Diseases, Critical Care, \& Environmental Medicine, Tulane University Health Sciences Center, New Orleans, Louisiana, USA

\section{Correspondence to}

Dr M Chadi Alraies, alraies@hotmail.com

\section{DESCRIPTION}

A 49-year-old woman with a medical history of hypertension and rheumatoid arthritis presented with severe bilateral hand pain due to arthritis. She was diagnosed with rheumatoid arthritis at the age of 20 years and has been on anti-inflammatory medications and steroids since then. She was treated with methotrexate for a short period of time, but this was stopped due to gastrointestinal intolerance. She has been on prednisone and ibuprofen only for the last 15 years and has been a nursing home resident for the last 5 years due to severe hand deformities and inability to use her hand to take care of herself. On examination, she had a remarkable hand deformity significant for ulnar deviation, boutonniere deformity, swan neck deformity and Z-thumb resulting in permanent deformity and impaired functioning (figures 1 and 2). After admission, she was started on higher dose ibuprofen and prednisone $60 \mathrm{mg}$ orally daily for controlling pain. She continued to refuse any disease-modifying

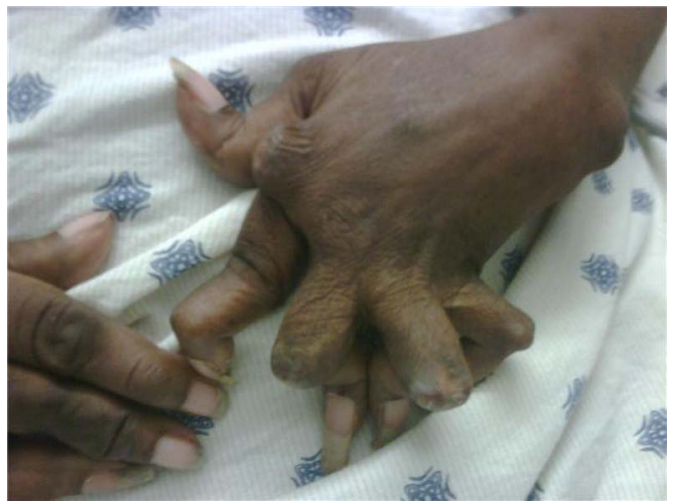

Figure 1 Left hand with severe rheumatoid arthritis deformity. Index finger with swan neck deformity, Z-thumb deformity and the rest of the fingers having Boutonnière deformity.

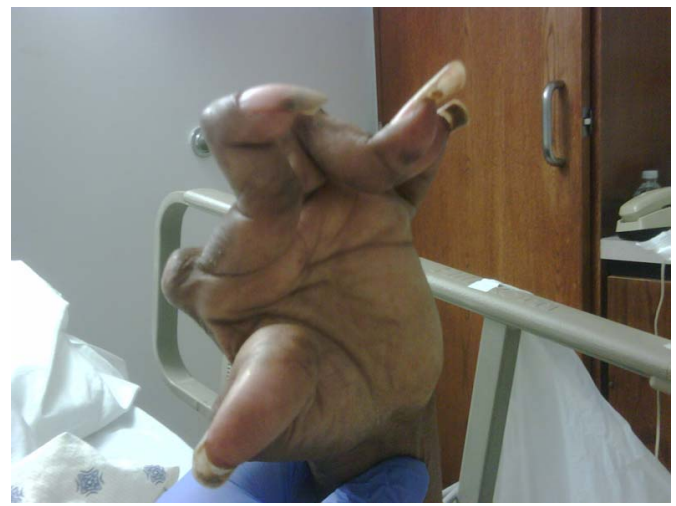

Figure 2 Same left hand with Swan neck deformity of the index finger and Boutonnière deformity of the third, fourth and fifth fingers. antirheumatic drugs. Hand surgery team saw her as well; however, she declined any surgical intervention, which could help her regain some functions of her hands. She was discharged back to nursing home with better-controlled pain.

Rheumatoid arthritis can be a disabling and painful condition, which can lead to a substantial loss of functioning and mobility if not adequately treated. The treatment focuses on controlling the symptoms and preventing joint damage. Various treatment modalities are available, which include tumour necrosis factor alpha blockers such as etanercept, infliximab and adalimumab. ${ }^{12}$

\section{Learning points}

- Rheumatoid arthritis is a chronic autoimmune disorder in which various joints in the body are inflamed, mainly affecting the small joints of the hands and feet, causing a painful swelling that can eventually result in bone erosion and joint deformity.

- The prevalence of rheumatoid arthritis is believed to range from $0.5 \%$ to $1.0 \%$ in the general population. Individuals with the HLA-DR1 or HLA-DR4 serotypes have an increased risk for developing the disorder with a tendency to develop severe deformities if not treated.

- Hand deformity can be severe and disabling similar to our case. Swan neck deformity involves hyperextension of proximal interphalangeal joint along with the flexion of distal interphalangeal joint; Z-thumb deformity consists of hyperextension of the interphalangeal joint and fixed flexion and subluxation of the metacarpophalangeal joint; and Boutonnière deformity is caused by a permanent flexion of the proximal interphalangeal joint and overextension of the distal interphalangeal joint.

Contributors All authors contributed by preparing, editing and finalising the manuscript.

Competing interests None.

Patient consent Obtained.

Provenance and peer review Not commissioned; externally peer reviewed.

\section{REFERENCES}

1 Saag KG, Teng GG, Patkar NM, et al. American College of Rheumatology 2008 recommendations for the use of nonbiologic and biologic disease-modifying antirheumatic drugs in rheumatoid arthritis. Arthritis Rheum 2008:59:762-84.

2 Vital EM, Emery P. Advances in the treatment of early rheumatoid arthritis. Am Fam Physician 2005;72:1002-4. 


\section{Images in...}

Copyright 2013 BMJ Publishing Group. All rights reserved. For permission to reuse any of this content visit http://group.bmj.com/group/rights-licensing/permissions.

BMJ Case Report Fellows may re-use this article for personal use and teaching without any further permission.

Become a Fellow of BMJ Case Reports today and you can:

- Submit as many cases as you like

- Enjoy fast sympathetic peer review and rapid publication of accepted articles

- Access all the published articles

- Re-use any of the published material for personal use and teaching without further permission

For information on Institutional Fellowships contact consortiasales@bmjgroup.com

Visit casereports.bmj.com for more articles like this and to become a Fellow 